\title{
Farmer led gross root level entrepreneurial initiatives for sustainable sugarcane production system in Tamil Nadu, India
}

\author{
C. Karpagam*, D. Puthira Prathap and P. Moovendan \\ Central Institute for Cotton Research, Regional Station, Coimbatore-641 003 (Tamil Nadu), INDIA \\ *Corresponding author. E-mail: karpsicar@gmail.com
}

Received: April 19, 2016; Revised received: September 25, 2016; Accepted: December 1, 2016

\begin{abstract}
The major objective of the study was to explore the rural entrepreneurial initiatives and its socio- economic impact among the sugarcane farmers across Tamil Nadu. Exploratory surveys, Focused Group Discussions (FDGs) and case study methods have been adopted. A total of seven successful entrepreneurial activities initiated by cane farmers, across different districts of Tamil Nadu were selected, purposively. The study revealed that entrepreneurial initiatives accomplished the needs of farmers and these either were developed by farmers themselves or with collaboration of sugar factories. Among seven entrepreneurial initiatives; 'two wheeler sprayer', 'tractor mounted sprayer', 'trichogramma production' and 'Agricultural Service Provider (ASP)' were initiated by the sugar factories under the Entrepreneurship Development Programme (EDP) in participatory mode. The other initiatives viz., organic jaggery powder and trash based vermi-compost production were initiated by farmers themselves. Budchip settling production was practiced by individual farmers as well as promoted by factories in participatory mode. It is also found that all seven entrepreneurial initiatives are profitable and sustainable. Further, the study found that the production cost for $1 \mathrm{cc}$ trichogramma is Rs. 16 and selling cost is Rs. 23/cc, thus farmer getting a net profit of Rs. 7/cc of Trico card. In case of budchip settling production, total cost incurred for production of one settling is around 60-85 paisa. Selling cost of one-month old settling is Rs. 1.25. Thus, a farmer gains a net profit of 40 paisa per settling
\end{abstract}

Keywords: Profitability, Social benefits, Social entrepreneurial initiatives, Sugarcane production system, Sustainability

\section{INTRODUCTION}

Gross root level entrepreneurial initiatives were ever sustainable with the social and economic system of the local people. Modern and outside driven technologies help better in augmenting the productivity, as compared to the local knowledge; but in the long run, the system faces more negative consequences and immense challenges. Promotion of entrepreneurship in rural area is a major step to increase economic development. Rural entrepreneurship is a purposeful activity initiating, promoting and maintaining economic growth. Rural entrepreneurship is not new to our culture. What it needs today is to nurture this spirit and instil it in the present and coming generations of both men and women. (Smitha et al., 2015). Identifying and promoting the entrepreneurial activities in rural area is one of the challenging task for government and policy makers. So, it is better to focus on various innovations developed by the local people and/or farmers at the grassroots, that is, at the field level, before it is too late (Ram Datt, et al., 2014). An alternative view is that local knowledge is a valuable and under-used resource, which can be studied, collected and incorporated into development activities. Neither of these views, though, is entirely satisfactory because of the static view of knowledge implied (Chambers et al., 1989; Warren,
1991; Long and Long, 1992; Scoones and Thompson, 1994 and Karpagam et al., 2014).

It is interesting to note that there are several novel rural entrepreneurial initiatives were taking place in sugarcane production system. Sugarcane is the next best cash crops then cotton. There are 46 sugar mills are involved in sugarcane cultivation in Tamil Nadu alone. Though the area under sugarcane in Tamil Nadu varied widely from 2.3 lakh hectares to 3.9 lakh hectares over the years in the new millennium (2000-01 to 2011-12), the productivity has almost been stabilized at around 105 tonnes/ha during this period (Ramasubramanian and Karpagam, 2014). Problems of stabilised productivity and decreasing remunerative cane prices leads for other allied entrepreneurial initiatives in sugarcane production system. Accroding to Kishor Bhanushali, developing entrepreneurs in agriculture will solve several problem viz. (a) reduce the burden of agriculture, (b) generate employment opportunities for rural youth, (c) control migration from rural to urban areas, (d) increase national income, (e) support industrial development in rural areas, (f) reduce the pressure on urban cities, etc. But in reality; if local farmer initiating a new venture; it is always subjected for large hue and cry by the research system. But, most of the grass root level initiatives generally go unnoticed. However, these initiatives fail at commercialization and dissemina- 
tion stages for lack of support from formal systems. Thus, extension research needs to work with both formal and informal R\&D set up, so that research for development becomes a reality (Chnadra et al., 2014). Keeping the importance of entrepreneurship development in agriculture and the paradigm shift from 'primary to secondary agriculture', Indian Council of Agricultural Research (ICAR) focused on development and establishment of agri-incubators, a new concept in the Indian agriculture expected to develop entrepreneurship in a big way. There are several initiatives taking place in rural area to develop entrepreneurs but still it needs to explore widely. Accordingly, keeping all these afore mentioned issues in view, a study was conducted on 'grassroot level social entrepreneurial initiatives' by the sugarcane farmers across Tamil Nadu, wherein, special emphasis was given on the 'social benefits' of such initiatives.

\section{MATERIALS AND METHODS}

As the study demands "case study" method was employed for this purpose. The research team surveyed 10 districts of Tamil Nadu viz., Tirunelveli, Karur, Erode, Theni, Pudukkottai, Coimbatore, Villupuram, Perambalur Thanjavur, and Ariyalur, to explore the grassroot entrepreneurial initiatives in sugarcane production system. Identifying the farmers practicing entrepreneurial activities is a difficult task felt by the research team. Therefore, several Focused Group Discussions (FDGs) were arranged with sugar factories

Methodology adopted for documentation of the entrepreneurial initiatives in Sugarcane Production System

Focused Group Discussions with sugar factory officials in the respective districts

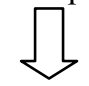

Entrepreneurial initiatives by sugar factories / farmers / collaborative were identified

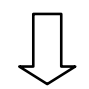

Focused Group Discussions were conducted with farmers in the respective villages

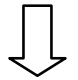

Seven successful farmers who practiced entrepreneurial activities in sugarcane production system were identified

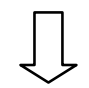

Each identified farmer was interviewed at their field<smiles>CCCCC</smiles>

Details of the entrepreneurail pracices were documented by audio and video gadgets personnel and farmers to identify the resourceful farmers who practice any innovative entrepreneurial practices in sugarcane production system. By using the deliberations, individual farmers were identified. The cases were selected purposively on the basis of the available data on the Sugarcane Breeding Institute, and the primary data collected from the focused group discussion with respective sugar factory personnel and the farmers group at the grass root, etc. Only such entrepreneurial initiatives were selected for this study, which were related to sugarcane production system. The farmers were interviewed in their respective farm filed with the help of an interview schedule. The interview schedule was semi structured and contains more questions about the details of the cases and economics of the entrepreneurial activities.

\section{RESULTS AND DISCUSSION}

The selected cases have its own scope, potential and limitations, hence all the cases were analysed for its scope, potential and limitations. Further the farmers' profile characteristics have also been studied. All the "Cases" were discussed with its' background, description, cost benefit analysis, social benefits. Further, Institutional interventions and support which required to upscale the initiatives has also been discussed.

Case-I: Organic jaggery powder - a value added business venture: (Individual farmer's initiative)

Shri. Anthonisamy from Puliangudi of Sivagiri Taluk, Tirunelveli district thought of producing Organic jaggery powder. Organically grown sugarcane was crushed and juice was extracted. The extracted juice was filtered and boiled without adding any chemicals. After removing the scum, the juice was further condensed till it becomes semi-soild and removed from the furnace. The semi-solid paste was cooled in a wide pan and scraped using wooden ladle to prepare organic jaggery powder. This finding has been supported by the study conducted by Nain et al. (2002) and they reported that jaggery production was a major traditional enterprise in sugar cane producing areas. At times, jaggery making was profitable to cane producers, than supply to sugar factory. The cost of sugarcane was the major cost item in jaggery production. The investment in jaggery processing units was found to be profitable.

Case-II: Sugarcane based vermi-compost for organic agriculture L: (Individual farmer's initiative) Shri. Gopalakrishnan, a farmer from Panikampatty village of Karur district produce sugarcane trash based vermi-compost for the past five years. Sugarcane trash, pressmud, cow dung, neem leaves, molasses and other farm wastes are spread on the floor in layers and Azospirillum and Phosphobacterium are sprinkled over it. The heap is allowed for twenty days for decomposing. After 20 days, earthworms are released and watered at three days intervals to maintain adequate moisture. After 2-3 months, compost will be ready. The 
C. Karpagam et al. / J. Appl. \& Nat. Sci. 8 (4): 2249-2255 (2016)

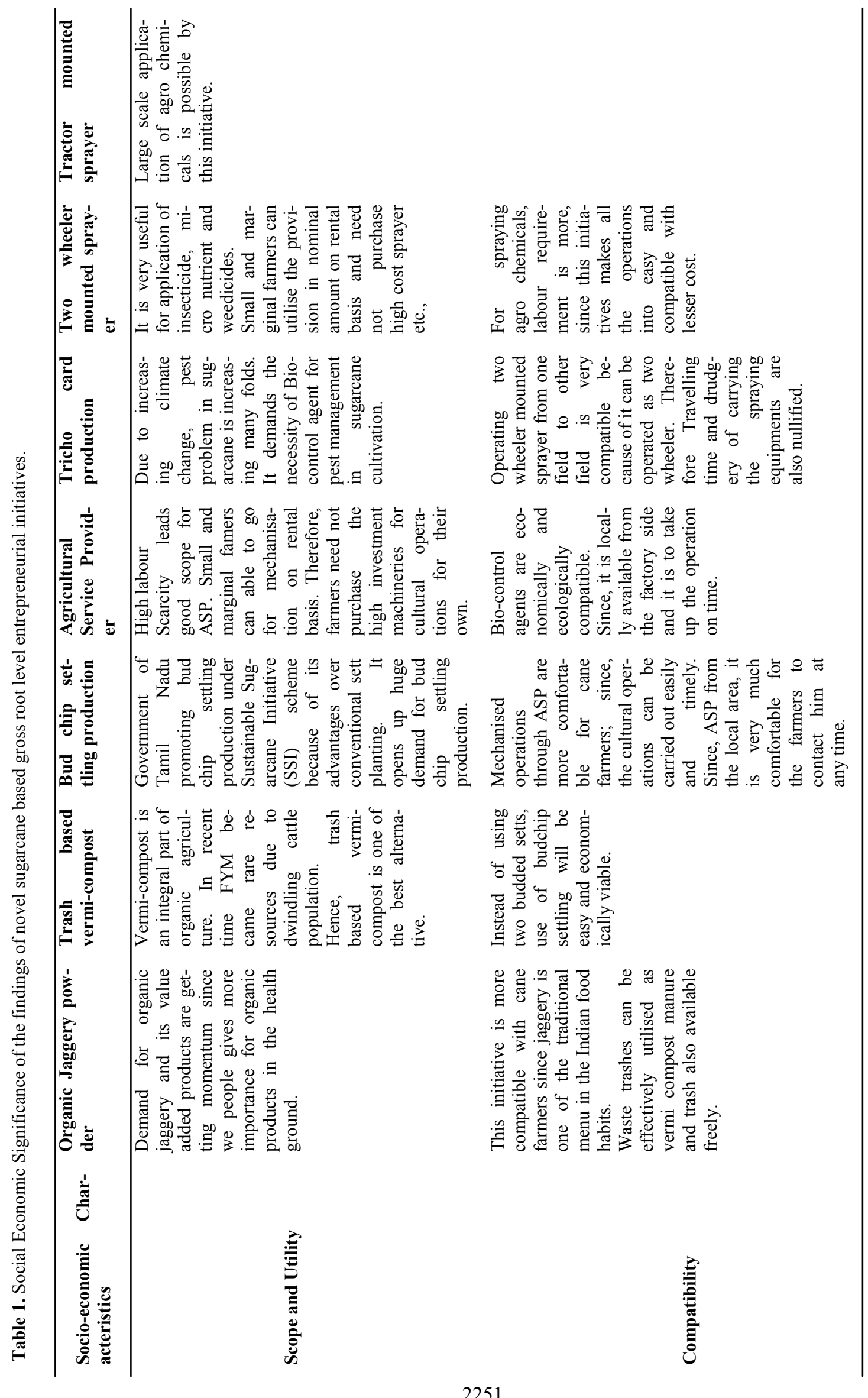


C. Karpagam et al. / J. Appl. \& Nat. Sci. 8 (4): 2249-2255 (2016)

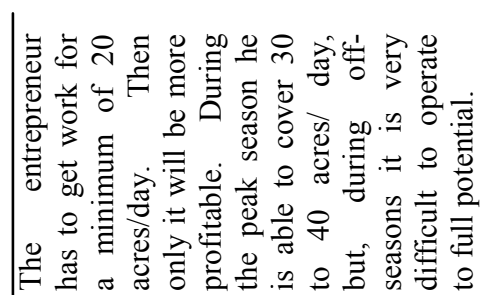

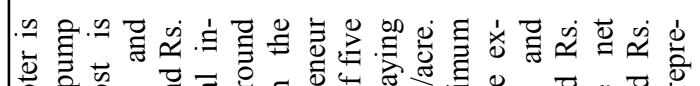

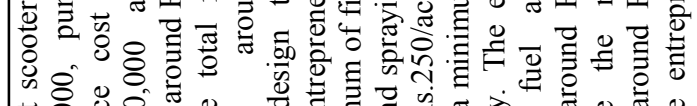

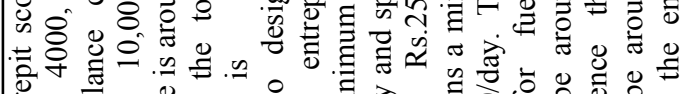

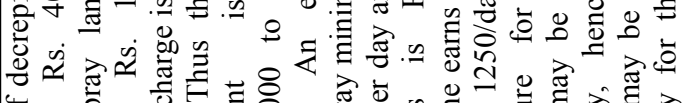

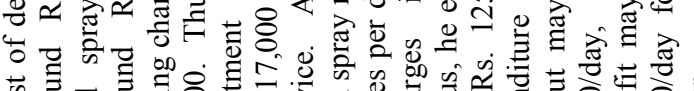

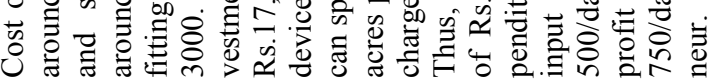

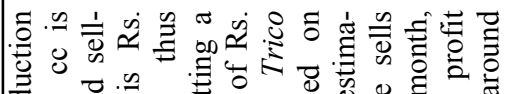

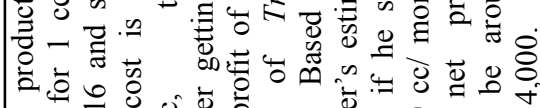

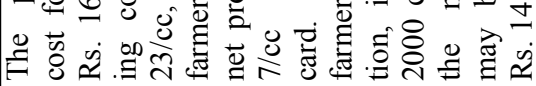

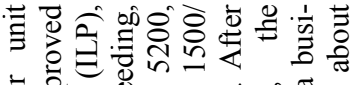

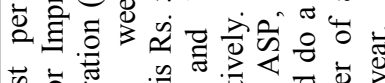

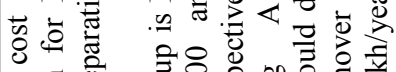

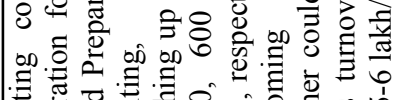

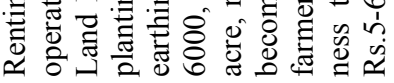

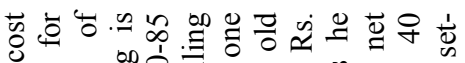

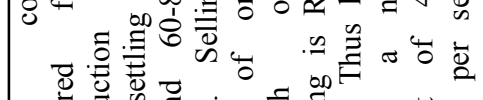

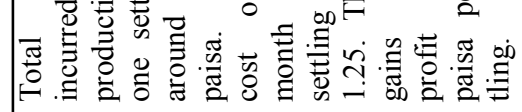

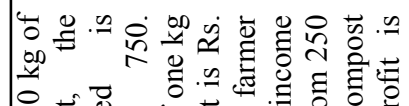

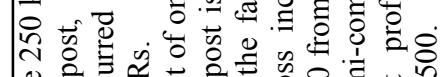

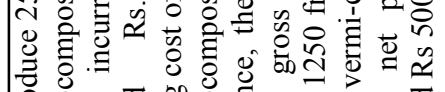

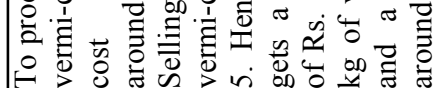

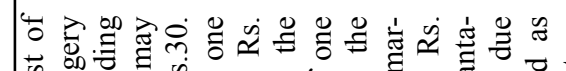

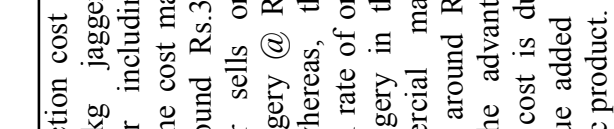

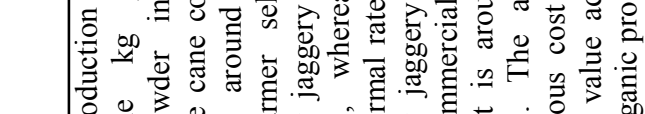

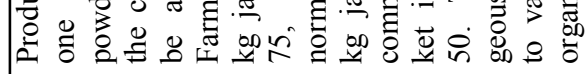

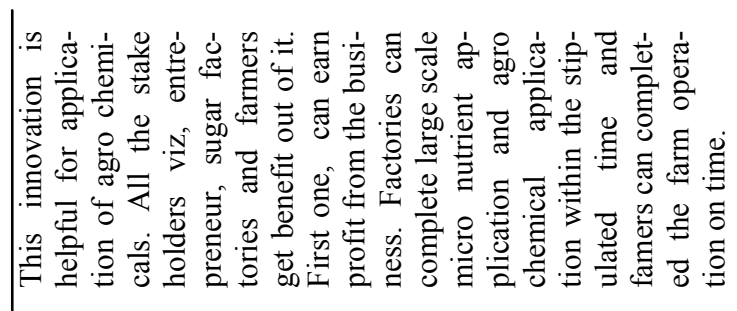

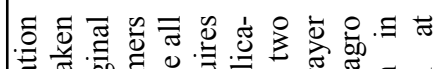

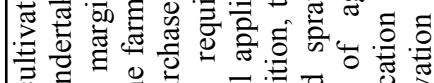

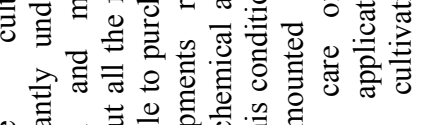

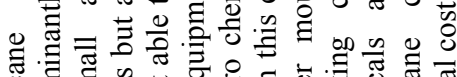

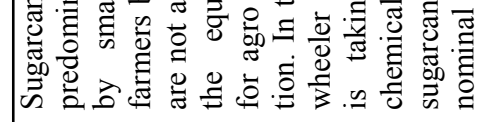

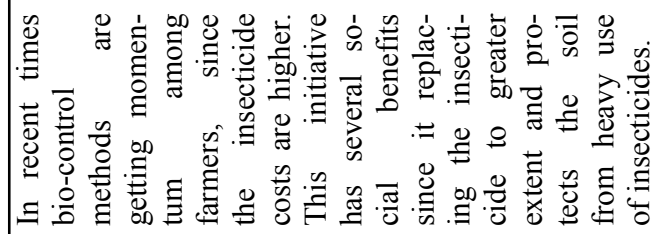

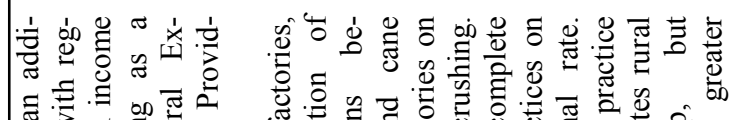

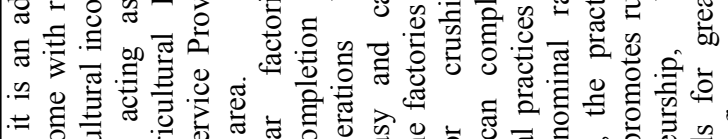

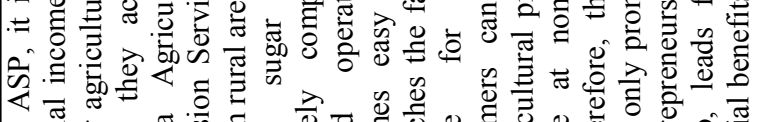

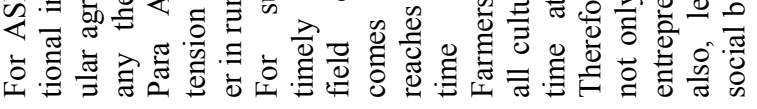

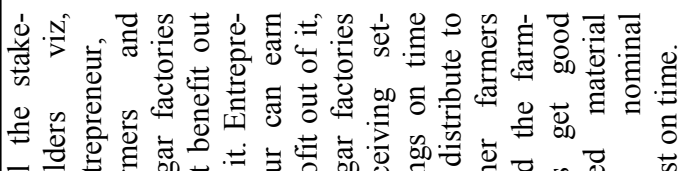

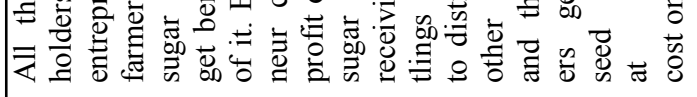

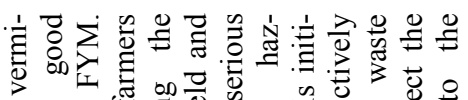

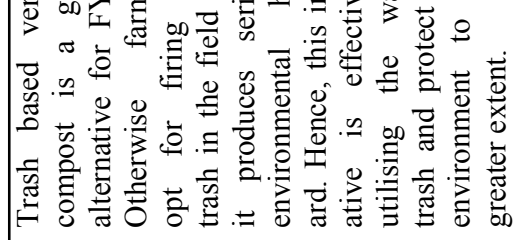

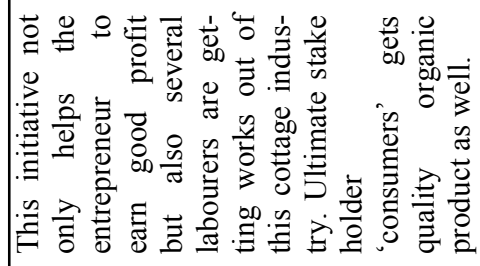
产 


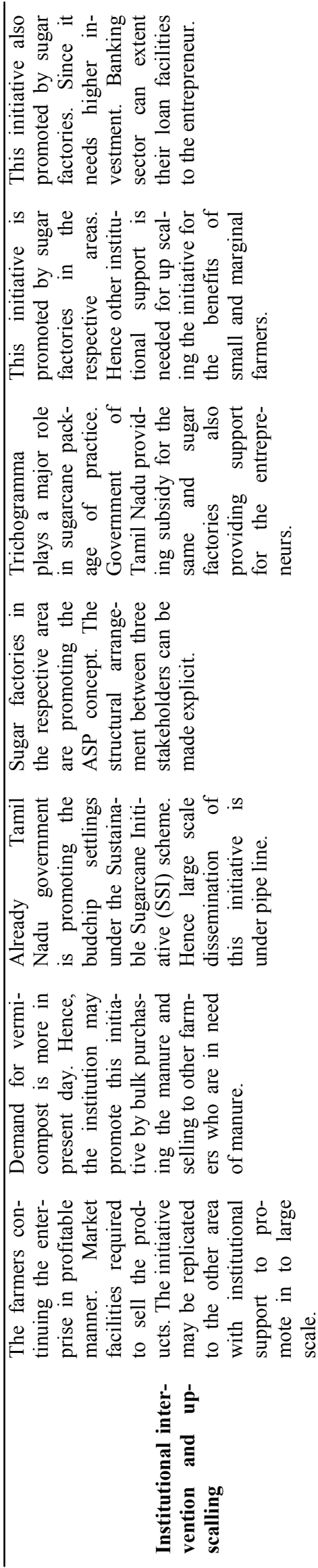

upper portion of the heap is collected and stored and the lower portion is sieved to separate earthworms. The benefits of sugarcane based vermicompost production is supported by the recent study conducted by $\mathrm{Ku}-$ mar et al. (2010) demonstrated that the compost produced by pre-decomposing of by-products of sugar processing industries (Sugarcane trash and bagasse), with efficient microbes (composting) followed by vermicomposting point towards the feasibility of an integrated system of vermicomposting to produce nutrient rich vermicompost.

Case-III: Budhip settling as a small scale business venture: (Individual \& Participatory initiative by sugar factory and farmers).

Shri. Mohanraj from Ramapuram village of Thalavadi Taluk in Erode District of Tamil Nadu produces settlings and sells to sugar factory on contract basis. The buds are scooped from cane by bud chipper and placed in pro trays filled with coir pith. The filled trays are placed one above the other and covered with gunny bags for a week. After a week, the sprouted buds with trays are transferred to green net houses and kept for three weeks with regular watering. Thus, the settlings are ready for transplanting within a month. The effectiveness of the budchip settling has been reported by several researchers. Biksham Gujja and Natarajan (2013) reported that sustainable sugarcane initiative (SSI) also known as "Chip bud technology" involves removal of buds from cane and raising nurseries results in drastically reduce the seed cane requirement, about 4-6 t/ha compared to conventional method of planting.

Case-IV: Agricultural service provider - ASP: (Participatory initiative by sugar factory and farmers). Shri. R. Raja is a farmer from Anthrapatii village acted as an Agricultural Service Provider (ASP) for sugar factory in his area. Machineries are hired out to take up agricultural operations in other farmer's field. There is a tripartite agreement between farmers, sugar factory and ASP. The ASP will carry out all the farm operations from preparatory cultivation to transport of harvested cane to the factory. Sugar factories debit the cost to the ASP's account by reception of receipts signed by the farmers and the same amount is deducted from the concerned farmer while paying cane price to the farmers. There are several support has been rented by sugar factories to the cane farmers. Todkari (2012) concluded that Shri Sant Damaji Co - operative sugar factory adopted various agricultural service providing activities viz., supply of molasses, supply of good quality seeds and other labour welfare programmes.

Case-V: Tricho card production - a small scale business venture: (Participatory initiative by sugar factory and farmers).

Shri. Karuppaiyan from Balaviduthi village undertakes Trichogramma production under the entrepreneurship development programme of a sugar factory in the area. The parasitoids are multiplied in the medium which 
has the mixture of $2.5 \mathrm{~kg}$ pearl millet seed, $100 \mathrm{~g}$ groundnut powder, $5 \mathrm{~g}$ dry yeast and $5 \mathrm{~g}$ sulphur. With this mixture, half cc rice moths (Corcyra cephalonica) are released and kept for 45 days in closed condition. The emerged adults are collected in the test tube and released into a chamber for laying eggs. Eggs are collected in a tray and exposed to ultra violet light in UV chamber to kill the host embryo but at the same time, permit parasitization.

Case-VI: Two wheeler mounted sprayer - an entrepreneurial initiative: (Participatory initiative by sugar factory and farmers).

Shri. S. Angappan from Vallipattu village has converted a old scooter into an effective sprayer by placing a tank in the pillion seat and attaching pump to the scooter's engine and used as a petrol engine operated sprayer. The spraying lance is around 100 metres long, so it can easily cover long distances as well. The pump inlet is connected to a pesticide container.

Case-VII: Tractor mounted sprayer - an entrepreneurial opportunity: (Participatory initiative by sugar factory and farmers).

Shri. Senthilkumar from Sarakadu village has converted a old tractor into an effective sprayer by placing two 1000 litres capacity tanks in the trailer. Two separate spraying lances of around 600 feet each are attached with each tank. One hp pump fitted nearer to the driver's seat and attached with the tractor engine. When the tractor engine is on, the pump will be switched on and sprayer can be operated. Since, spraying lance has 600 feet length, it can be operated from faraway places and can cover long distance as well.

Socio-economic significance of the findings: The study found that all the seven grass root level entrepreneurial initiatives were demand driven and successfully meet out the needs of the local farmers. Further, the initiatives were not only beneficial for the farmers who initiated but also it beneficial for society as whole.

\section{Conclusion}

The investigation on this research issue is a maiden attempt to explore gross root level entrepreneurial activities in sugarcane production system. The study revealed that different entrepreneurship initiatives opened up avenues for social scientists to promote community based ventures and to develop entrepreneurship in sugarcane based cropping system. In case of budchip settling production; both the stakeholders viz, farmers and factories gets benefit out of it. Farmers can earn money thorough the business and the factories are getting settlings on time to distribute to the other farmers in the area. In another case "vermicompost' production; it is an integral part of organic agriculture. Majority of the farmers are not able to take up the vermi- compost production for their own requirement, as it requires more time and labour. But farmers are ready to apply vermi-compost in their field if they get it on cost basis. Even, they are ready to pay Rs. 7000-8000/ tonne. Hence, this entrepreneurial avenue have greater scope for further exploration. Several societal problems in sugarcane cultivation viz. labour scarcity (two wheeler and tractor mounted sprayer), depletion of natural resources (vermicompost production), stakeholder conflict management (Agricultural Service Provider), human health deterioration (Organic jaggery powder), ill effects of pesticides (Tricho card production) were addressed by the these entrepreneurial initiatives. Among the seven initiatives, bud chip settling production and tricho card production are directly supported by the Government of Tamil Nadu and other five initiatives were still in localised confined stages. Therefore, Government and other institutional support are needed for further outscaling of the initiatives for larger benefit of the society.

The study also found that the grass root level entrepreneurial initiatives needed lesser investment, greater utility, more social benefits (localised benefits are more) and higher sustainability compared to modern high investment entrepreneurial ventures. When these initiatives are recognised by the institution and government then it leads for holistic rural development through sugarcane cultivation. This study has been opened new vistas of extension research apropos 'novel sugarcane based gross root level entrepreneurial initiatives' in our country.

\section{ACKNOWLEDGEMENTS}

I express my sincere thanks to all the respondents for their valuable inputs for this study and I thank Director, Sugarcane Breeding Institute for permission to take up this challenging task.

\section{REFERENCES}

Biksham, Gujja. and Natarajan, U.S. (2013). Sustainable sugarcane initiative - improves yield and reducing ecological footprint. LEISA India, 15 (1)

Chambers, R., Pacey A. and Thrupp, L.A. (1989). Farmer first: Farmer innovation and agricultural research. Intermediate Technology Publications, London

Chandre, Gowda., Dixit, M.J., Burman, S.R. and Ananth, P.N. (2014). Extension research and technology development, Agricultural Extension in South Asia blog. Retrieved May, 182015 from http://www.aesa-gfras.net

Karpagam, C., Murali, P., Bhaskaran, A., Rajula shanthy, T. and Puthira prathap, D. (2014). An Inventory of farmers' Practices for Inclusive development in Sugarcane Production System. SBI Publication

Kumar R., Verma D., Singh BL., Kumar U. and Shweta. (2010). Composting of sugarcane waste by-products through treatment with microorganisms and subsequent vermicomposting. Bioresource Technology, 101: 67016711

Long, N. and Long, A. (1992). Battlefields of knowledge: The interlocking of theory and practice in social research and development. Rout ledge, London

Nain N., Khatkar, RK. and Singh, VK. (2002). Role of sug- 
C. Karpagam et al. / J. Appl. \& Nat. Sci. 8 (4): 2249-2255 (2016)

arcane processing industry and efficiency of processing in Haryana. Indian Journal of Agricultural Marketing, 16: $97-103$

Ram Datt., Sujeet k Jha., Ata-UI-Munim Tak. and Nandani Salaria. (2014). Case studies on attributes of few dairy based innovations developed at the grassroots across India, Indian J traditional knowledge, 13(3): 564-573

Ramasubramanian, T. and Karpagam, C. (2014). FAQs on Early Shoot Borer. Kissan world, 41(9): 19 - 21

Scoones, I. and Thompson, J. (1994). Beyond Farmer First. IT Publications, London.

Smitha, S.S., Ramkrishn, G.S. and Samuel mores, G. (2015).
Women entrepreneurship in the rural environment. International Journal of Advance research in Computer Science and Management Studies, 3 (2) :138-143

Todkari, G.U. (2012). Role of co-operative sugar factories in rural development: A case study of Damaji Sugar factory, Mangalweda. International Journal of Agricultural Sciences, 4 (1): 168-171

Warren, D. (1991). The role of indigenous knowledge in facilitating a participatory approach to agricultural extension, In: International Workshop on Agricultural Knowledge Systems, Bad Boll, Germany 